\title{
THE IMPACT OF INNOVATION AND FOREIGN DIRECT INVESTMENT (FDI) AND ITS INTERACTION TO EXPORT VALUE OF HIGH- TECHNOLOGY PRODUCTS OF ASIAN-10
}

\author{
Nadia IImi*1 \\ ${ }^{1}$ Faculty of Economic and Business, Universitas Airlangga, Indonesia
}

\begin{abstract}
High-technology product is highly depend on science and technology innovation that leads to renewal or improvement of products and services. Foreign direct investment has spillover effects in the form of transfer of foreign technology, managerial capabilities, and improved international competitiveness for domestic companies. The objectives of the study is to analyze the impact of innovation and Foreign Direct Investment (FDI) on the export of high-technology products Asian-10 countries. This study utilize the gravity model framework and panel dataset from 10 countries in Asian and 29 trading partners country with the period from 2006 to 2013. The results show that innovation of exporter countries, FDI of exporter and importer countries, as well as the interaction between FDI and innovation of exporter countries have a positive and significant impact, and the interaction between FDI and innovation of importer countries have a negative and significant impact on exports of high-technology Asian-10. In this study also found that the innovation of importer countries do not have a significant impact on the export of high-technology products Asian-10 countries from 2006 to 2013.
\end{abstract}

Keywords: Innovation, Foreign Direct Investment, Gravity Model, Export JEL : F1, F2

To cite this document: IImi, N. (2017). The Impact of Innovation and Foreign Direct Investment (FDI) and Its Interaction to Export Value of High-Technology Products of Asian-10. JDE (Journal of Developing Economies) 2(1), 47-57.

\section{Introduction}

Economic growth in Asian has significantly increased in the last two decades. The main supporting factor in Asian's economic growth is trade and investment (Ismail, 2013). Asian countries pattern of trade has moved from import substitution to export-oriented and technology-based trading. Asian success continues as the Asian region begins to play an important role in producing manufactured goods for the global market. East Asia later became synonymous as 'factory of the world' (Kimura and Obashi, 2011). Asian-10 countries'exports derived from $76.3 \%$ of manufacturing exports and $29.7 \%$ of high-technology products exports. This export rate is higher than the world manufacturing and high- technology products exports rate which was respectively $68.4 \%$ and $18.2 \%$. High-technology product is highly based on science and technology innovation that leads to product and service renewal or enhancement. According to Euro Statistics (2003), product can be said as high-technology if there is a big involvement of Research and Development (R\&D) expenditure in manufacture product. The extent involvement of R\&D expenditure can be seen through the ratio of R\&D expenditure/

JDE (Journal of Developing Economies) p-ISSN: 2541-1012; e-ISSN: 2528-2018 DOI: http://dx.doi.org/10.20473/jde.v2i1.5095

Open access under a Creative Commons Attribution 4.0 International

(CC-BY) 
total sales. The high ratio is used to compensate the high involvement of high skilled labor, sophisticated technology, and capital expenditure. High-technology products are divided into nine categories, namely Aerospace, Computers/Office Machine, Electronic-telecommunications, Pharmacy, Scientific Instruments, Electrical Machinery, Chemistry, Non-Electrical Machinery, and Armament.

Foreign investment is considered as an important element of industrial development and economic growth of a country. Not only as capital inflow, but foreign investment also has a spillover effect in the form of transfer of foreign technology, managerial capabilities, and improved international competitiveness for domestic companies. Foreign investment and international trade has long since become a major source of international technology transfer (Keller, 2009).

Grossman and Helpman (1994) states that import can help to bring innovations which are not available in the domestic economy, as well as local researchers can gain insight from this innovation. Access to foreign innovations will provide access to trade in order to improve technological diffusion and economic growth. Innovation can provide the following benefits: (1) Increasing the quality of human life through new discoveries that help in the process of fulfilling the needs of human life, (2) Enabling a company to increase sales and profits, (3) Increasing the ability to distribute creativity for the creation of something new, (4) the diversity and variety of products in the market (Rogers, 2003).

According to Onodera (2008), trade and innovation can be explained in two ways. First, trade and investment as the holder of the primary roles of increasing innovation through various means such as technology transfer, competition effect, and the spillover effect. Secondly, innovation can also affect trade, especially trade in products with high technology content. Innovative companies that produce high-technology products will present alternatives for exporting products overseas, licensing the technology to third parties or investing overseas to exploit the benefits of innovation. Innovation can be either product innovation (through the introduction of new products) or process innovation (through the improvements in the production, distribution or support of goods and services).

Innovation plays an important role for the exporter countries of high-technology products as a representation of the country's ability to produce innovative products for domestic and export to imitating countries. Meanwhile, importing countries with innovation activities can imitate production through learning by import process. Innovation is not just limited to new products but also includes production processes, services, supply chain, design, marketing and distribution.

Gravity Model is often used in measuring the level of trade between two countries. The main variables used to estimate the gravity model are Gross Domestic Product (GDP) and distance variables. As the study progresses, the gravity model variables used continue to grow, such as the addition of variable income gaps in the model (Krugman et al., 2012:10). Higher income levels in exporter countries show a high level of production, which increases the availability of goods for the export of high-technology products. This suggests the idea that larger and richer countries are more likely to have more trade in the high-technology product sector. Distance is a proxy for transportation costs, which indicates that the closer the distance, the lower the cost of transport and the higher the trade volume between the two countries. The smaller income gap explains that the intensity of trade will increase between two countries with the same level of income (Carbaugh, 2010). On the other hand, the larger Income gap suggests that trading occurs due to differences in GDP per capita, thus supporting the theory of comparative advantage.

This study discusses how the impact of GDP, income gap, distance, innovation, FDI, and the interaction between innovation and FDI on exports of Asian-10 countries's high- technology products simultaneously or partially. The academic contribution of this study is the use 
of interaction variables between Foreign Direct Investment (FDI) and innovation, assuming the possibility that innovation may occur through FDI channels. Thus it can be seenwhether innovation through FDI investment reflects only the learning process by importing orbeing able to enter the stage where countries emulate and produce high-technology products and reduce the import of high-technology products.

\section{Literature Review Comparative Advantage Theory (David Ricardo)}

This theory shows that if in a country's trade is superior in absolute terms in the production of all goods, less efficient country can still trade by applying specialization in producing and exporting commodities with smaller absolute losses (commodities with comparative advantage) and importing commodities Which has greater absolute losses (commodities that have comparative losses) (Carbaugh, 2010:34).

\section{Heckscher-Ohlin Theory (H-O Theory)}

Before entering into the discussion of the $\mathrm{H}-\mathrm{O}$ theory, this paper will slightly reveal the weaknesses of classical theory that led to the emergence of $\mathrm{H}-\mathrm{O}$ theory. Classical Theory Comparative advantage explains that international trade can occur because of differences in productivity of labor (factors of production explicitly stated) between countries (Salvatore, 2005:43). However, this theory does not provide an explanation of the causes of the differences in productivity. $\mathrm{H}-\mathrm{O}$ theory then tries to explain the cause of the difference in productivity. $\mathrm{H}-\mathrm{O}$ theory states the causes of productivity differences because of the number or proportion of factors of production owned (endowment factors) by each country, thus further causing the difference in price of the resulting product.

\section{Foreign Direct Investment (FDI)}

According to Salvatore (2005:126), International capital flows are defined to be two kinds, portfolio investment and direct investment. Direct investments are investments in real assets, such as factories, inventories, where capital and management are included in these investments to control the investments. Direct investment is usually seen in the acquisition practice of a company or where a company buys all or most of the ownership of another company. In the international situation, direct investment is usually done by multinational companies that do business such as in the field of natural resources, manufacturing, and services. Direct investment is often associated with multinational corporations as indicated bythe current production phenomenon, where production is carried out at factories that locatedin two or more countries but remains in control and regulation by headquarters in one country.

\section{Technological Gap Model}

The technological gap model was first developed by Posner in 1961. According to this theory, a large number of trade among industrialized nations is based on the emergence of new products and processes of production or new technologies (Salvatore, 2005). The existence of new production processes and new products often provide a temporary monopoly position for certain companies or countries in the international market. Temporary monopoly position is based on patent or copyright which gives the owner privilege to exploit what patent protected exclusively.

\section{Product Cycle Theory}

This product cycle theory was developed by Vernon in 1966. Basically this theory relates to the life cycle of a new product and its impact on international trade. There are two categories of countries described in this theory namely innovating country and imitating country. Innovating country is a country with higher technological progress compared to other countries so it can introduce new products. This theory also confirms that innovating countries is a country which capable of producing new goods because it benefits from lower 
cost of production in the country. While imitating country is a country that imitated the production of innovating country. Usually the production of this country has a lower quality than the production of innovating country. Vernon's product cycle theory explains the importance of innovation for the country of export of high-technology products, as a representation of a country's ability to produce innovative products for domestic area and export to imitating countries.

\section{Gravity Model}

The gravity model is a model used to analyze the flow of goods bilaterally between two parties having geographical distances. This model is inspired by Isaac Newton's Law of Universal Gravitation theory of 1687, which explains that the interaction between two objects is proportional to their mass and inversely proportional to each other's distance (Krugman et al., 2012:10).

\section{Analysis Model}

The analysis model used in this study is an econometric model using panel data regression. The gravity model used is a model for calculating the size of bilateral trade between two countries. The model used in this study is a modification of the model of previous research of Ismail (2013). The econometric model used can be formulated as follows:

$$
\begin{aligned}
& \mathrm{LHTE}_{\mathrm{ijt}}=\alpha_{0}+\beta_{1} \mathrm{LGDP}_{i t}+\beta_{2} \mathrm{LGDP}_{\mathrm{jt}}+\beta_{3} \mathrm{LDIST}_{\mathrm{ij}}+\beta_{4} I N \text { NOV }_{i t}+\beta_{5} \text { INNOV }_{j \mathrm{jt}}+\beta_{6} \mathrm{LINCOMEGAP}_{\mathrm{ijt}} \\
& +\beta_{7} \mathrm{FDl}_{\mathrm{it}}+\beta_{8} \mathrm{FDl}_{\mathrm{jt}}+\beta_{9}\left(\mathrm{FDl}_{\mathrm{it}} \times \mathrm{INNOV}_{\mathrm{it}}\right)+\beta_{10}\left(\mathrm{FDI}_{\mathrm{jt}} \times \mathrm{INNOV}_{\mathrm{jt}}\right)+\varepsilon_{\mathrm{ijt}}
\end{aligned}
$$

Where:

LHTE $_{\mathrm{ijt}}$

$=$ Exports value of high-technology products from country $i$ to country $j$ in yeart.

$\mathrm{GDP}_{\text {it }} \quad=$ GDP country $\mathrm{i}$ in year $\mathrm{t}$.

$\mathrm{GDP}_{\mathrm{jt}} \quad=$ GDP country $\mathrm{j}$ in year $\mathrm{t}$.

DIST $_{i j} \quad$ = Distance between country $\mathrm{i}$ and country $\mathrm{j}$.

INNOV $_{\text {it }} \quad=$ Innovation of country $i$ in year $t$.

INNOV $_{\mathrm{jt}} \quad=$ Innovation of country $\mathrm{j}$ in year $\mathrm{t}$.

INCOMEGAP $_{\mathrm{ijt}} \quad=$ Income gap country $\mathrm{i}$ and country j.FDl ${ }_{\mathrm{it}}=$ FDI country $\mathrm{i}$ in year $\mathrm{t}$.

$\mathrm{FDI}_{\mathrm{jt}} \quad=\mathrm{FDI}$ country $\mathrm{j}$ in year $\mathrm{t}$.

$\left(\mathrm{FDI}_{i \mathrm{t}} \times \mathrm{INNOV}_{\mathrm{it}}\right) \quad=$ Interaction between $\mathrm{FDI}$ country $\mathrm{i}$ in year $\mathrm{t}$ with innovation country $\mathrm{i}$ in yearl t.

$\left(\mathrm{FDI}_{\mathrm{jt}} \mathrm{x} / \mathrm{NNOV}_{\mathrm{jt}}\right) \quad=$ Interaction between $\mathrm{FDI}$ country $\mathrm{j}$ in year $\mathrm{t}$ with innovation country $\mathrm{j}$ in yeart.

$\varepsilon_{\mathrm{ijt}} \quad=$ Error term.

\section{Research Methods}

There are two types of variables used, dependent variable and independent variable. Dependent variable used in this study is the export of high-technology products in Asian-10 countries $\left(\mathrm{HTE}_{\mathrm{ij}}\right)$. Independent variables used in this study consist of GDP of exporter country $\left(G D P_{i}\right), G D P$ of importer country $\left(G D P_{j}\right)$, distance between exporter and importer country (DIST $\left.T_{i j}\right)$, innovation of exporter country (INNOV $\left.{ }_{i}\right)$, innovation of importer country (IN$\mathrm{NOV}_{\mathrm{j}}$ ), Income gap exporter country and importer country (INCOMEGAP $\mathrm{ij}_{\mathrm{ij}}$ ), FDI of exporter country $\left(F D I_{i}\right), F D I$ of importer country $\left(F D I_{j}\right)$, Interaction between $F D I$ exporter country and innovation of exporting country $\left(\mathrm{FDI}_{\mathrm{i}} \times \mathrm{INNOV}_{\mathrm{i}}\right)$, Interaction between FDI importer country and innovation of importer country $\left(\mathrm{FDI}_{\mathrm{j}} \times \mathrm{INNOV}_{\mathrm{j}}\right)$.

The data types used in this study are secondary data and are panel data from 10 Asian countries (China, Philippines, Hong Kong, India, Indonesia, Japan, South Korea, Malaysia, Singapore, Thailand) and 30 trading partner countries (USA, Australia, Austria, Belgium, Brazil, 
Canada, China, Denmark, Philippines, Finland, Hong Kong, India, United Kingdom, Ireland, Italy, Germany, Japan, South Korea, Malaysia, Mexico, Norway, Portugal, France, Spain, Sweden, Switzerland, Thailand, Turkey) as trading partners. Data used consist of eightyears period of time starting from 2006 to 2013.

Data used in this study were obtained from several online sources. High-Technology Export Data were obtained from United Nation Comtrade based on SITC-Rev.3, Gross Domestic Product (GDP), innovation, income gap, and Foreign Direct Investment (FDI) data were obtained from World Development Indicators (WDI). Distance data between the two countries were obtained from the Geo Bytes website.

\section{Results And Discussion}

Based on the estimation using panel data that has been done, it is obtained that from ten independent variables used there are nine variables that have a significant impact and one variable that has no significant impact on exports of high-technology products of Asian-10 countries with 29 trading partners countries from 2006 to 2013. Dependent variable that have no significant impact on exports of Asian-10 high-technology products is innovation of importer countries (INNOV $\mathrm{j}$ ).

The export country's Gross Domestic Product (GDP) has a positive and significant impact on exports of Asian-10's high-technology products from 2006 to 2013. GDP is a proxy for economic size in exporter countries. Thus, the greater the value of GDP in the exporter country, the greater the overall value of all goods and services produced in an area within a given time period. This result is in line with Ismail (2013) study which states that GDP of exporter country has an impact on the export of high-technology products from the supply side, where high GDP in exporter country will show an increase in production capability as well as an increase in export offer of high-technology products of Asian-10 country from 2006 to 2013.

The importer country's Gross Domestic Product (GDP) has a positive and significant impact on exports of Asian-10 country high-technology products from 2006 to 2013. GDP of importer country is a proxy of the importer country's economic size. This explains that the greater the value of GDP in importer country, the greater the potential for market demand, so that high GDP in importer country will increase the value of exports of Asian-10 country high-technology products from 2006 to 2013. The realization of imports is determined by the ability of the country to buy, which means the amount of import depends on the national income level of the country. The higher the income level and the lower the country's ability to produce a product, the higher the imports will be (Deliarnov, 2003: 89).

Based on the estimation, the distance between exporter and importer countries has a negative and significant impact on the export of Asian-10 high-technology products from 2006 to 2013. Distance is a proxy for transportation costs. This indicates that the shorter the distance between Asian-10 countries and their 29 trading partner countries, the lower the transportation cost. Low transportation costs will lead to an increase in trade volume betweenthe two countries.

Table 1: Equation Estimation Result on GLS Panel Model

\begin{tabular}{ll}
\hline Dependent Variable: HTEijt & \\
\hline GDPit & 0.468353 \\
\hline & {$[0.0000]^{* * *}$} \\
\hline GDPjt & 1.033859 \\
\hline & {$[0.0000]^{* * *}$} \\
\hline DISTij & -1.209346 \\
\hline & {$[0.0000]^{* * *}$} \\
\hline
\end{tabular}




\begin{tabular}{ll}
\hline Dependent Variable: HTEijt & \\
\hline INNOVit & 0.214342 \\
\hline INNOV $_{\text {jt }}$ & {$[0.0000]^{* * *}$} \\
\hline & -0.020045 \\
\hline INCOMEGAPijt & {$[0.3001]$} \\
\hline & -0.034244 \\
\hline FDlit & {$[0.0216]^{* *}$} \\
\hline & 0.037861 \\
\hline FDljt & {$[0.0000]^{* * *}$} \\
\hline & 0.166854 \\
\hline FDlit x INNOVit & {$[0.0000]^{* * *}$} \\
\hline & 0.016473 \\
\hline FDljt x INNOV $j t$ & {$[0.0000]^{* * *}$} \\
\hline & -0.062000 \\
\hline C & {$[0.0000]^{* * *}$} \\
\hline & -10.80171 \\
\hline Obs & {$[0.0000]^{* * *}$} \\
R-squared & 1415 \\
Adjusted R-squared & 0.960260 \\
Protatistics & 0.959977 \\
\hline
\end{tabular}

Notes: *** Significant at 1\%, ** Significant at 5\%, * Significant at $10 \%$ Numbers in [ ] are p-value

Innovation in exporter country has a positive and significant impact on export value of Asian-10 high-technology products from 2006 to 2013. The high innovation owned by exporter country will increase the export volume of high-technology products. The second phase of the product life cycle theory is evident in the Asian-10 countries from 2006 to 2013. The phase is the Product Growth Phase that shows that the innovating country will have the ability to monopolize the market both domestically and abroad, because no other country is able to meet the demand for certain products (Salvatore, 2005: 182).

The estimation results that have been made mention that innovation in the importer country did not have a significant impact on the increase in exports of high-technology products Asian-10 countries from 2006 to 2013 . From these results it can be seen that the innovations owned by importer countries have not been able to compete with innovations owned by exporter countries. As mentioned earlier, Asian-10 country from 2006 to 2013 proved to be the second phase of the theory of the product life cycles, the product growth phase, indicating that the innovating country will have the ability to monopolize the market, both domestically and abroad, because no other country is able to meet the demand for certain products.

The income gap between exporter and importer countries based on the estimation results shows a negative and significant impact on exports of Asian-10 high-technology products from 2006 to 2013. This explains that Asian-10 countries tend to trade with trading partner countries that have similar income levels. The results of this study prove the theory of overlapping demand compiled by Staffan Linder in 1960, which states that the intensity of international trade will increase if both countries have similar income (Carbaugh, 2010). This research also has the same result with research that has been done before by Ismail (2013) which states that because high-technology products can't be separated from high cost and high price, so that the country of potential export destination is a country that has similarity inhigh income level. 
Foreign Direct Investment (FDI) in exporter countries shows a positive and significant impact on exports of Asian-10 high-technology products from 2006 to 2013. FDI is a proxy for technology spillovers in exporter countries. FDI is considered to bring in technology through technology transfer, management and expertise brought by investor countries (Grossman and Helpman, 1994). In Asian-10 countries, it is evident that FDI contributes to the development of innovation activities, which in turn will increase theproductivity of a country. It is this productivity increase which then increases exports of Asian-10's high-technology products from 2006 to 2013.

FDI in importer countries showed a positive and significant impact on exports of high-technology products Asian-10 countries from 2006 until 2013. It is interesting that the coefficient of FDI importer country has bigger value which is equal to 0.16685 , compared with coefficient value of exporter country FDI which is only equal to 0.03786 . From these results it can be concluded that FDI in importing countries would have a greater influence on the export of high-technology products of Asian-10. The presence of multinational companiesin importing countries is able to increase imports through increased demand for imported supplies, such as raw materials and intermediate products, as well as capital goods from home countries. At the beginning of the FDI phase, imports of equipment, machinery, provision of facilities and expertise, all contribute to increased imports. This is due to the high tendency of FDI companies to import capital goods, intermediate goods and services that are not available in the host region (Hailu, 2010).

The interaction between FDI and innovations in exporter countries based on the estimation results shows a positive and significant impact on exports of high-technology products Asian-10 countries from 2006 to 2013 . This study proves that with innovation through FDI, the productivity of a country can be improved and more efficient. Thus, an increase in the interaction between innovation and FDI in exporter countries will increase the value of exports of high-technology Asian-10 countries from 2006 to 2013. Fu (2007) find that FDI has a positive and significant impact on the overall capacity of the regional innovation. The intensity of FDI are also positively associated with efficiency innovations in the area of the host region.

The interaction between FDI and innovation in the importer country based on the estimation results indicates a negative and significant impact on the export of high- technology product of Asian-10 countries from 2006 to 2013. Interaction variables between FDI and innovation in importer countries are used by assuming the possibility that innovationmay occur through FDI. This increase in interaction between FDI and innovation in this importing country shows that innovation through FDI investment can go into the stage where countries are imitating and producing high-technology products and reducing the import of high-technology products. The high interaction between innovation and FDI in importer countries will reduce the value of high-technology products export, because in this condition the importer country has been able to duplicate the product.

\section{Conclusion}

Based on the results of research and discussion that has been discussed earlier, it can be obtained the following conclusions:

1. GDP, income gap, distance, innovation, FDI, and interaction between innovation and FDI are simultaneously have a significant impact on the export of Asian-10 high-technology products.

2. GDP, income gap, distance, innovation, FDI, and interaction between innovation and FDI are partially have a significant impact on the export of Asian-10 high-technology products.

a. GDP of exporter countries has a positive and significant impact on exports of Asian10 high-technology products from 2006 to 2013. If there is an increase in exporter's GDP, there will also be an increase in exports of Asian-10 high-technology products. 
b. GDP of importer countries has a positive and significant impact on exports of Asian10 high-technology products from 2006 to 2013. The higher the exporter's GDP, the higher the exports of Asian-10 high-technology products.

c. The distance between exporter and importer countries has a negative and significant impact on exports of Asian-10 high-technology products from 2006 to 2013. The negative sign on the test results of this variable indicates that if there is an increase inthe distance between exporter and importer countries, then the export of high- technology products of Asian-10 countries will decrease.

d. Innovation of exporter countries has a positive and significant impact on exports of Asian-10 high-technology products from 2006 to 2013. The high innovation in the exporter countries will increase the exports of Asian-10 high-technology products.

e. Innovations of importer countries have no significant impact on the exports of Asian-10 high-technology products.

f. Income gap between exporter and importer countries had a negative and significant impact on exports of Asian-10 high-technology products from 2006 to 2013. The results of this study explain that Asian-10 countries tend to trade with trading partner countries that have similar income levels.

g. FDI of exporter countries has a positive and significant impact on exports of Asian-10 high-technology products from 2006 to 2013. An increase in FDI of exporter countries will lead to an increase on the exports of Asian-10's high-technology products.

h. FDI of importer countries has a positive and significant impact on exports of Asian10 high-technology products from 2006 to 2013. If there is an increase in importer's $\mathrm{FDI}$, there will also be an increase in exports of Asian-10 high-technology products.

i. Foreign Direct Investment (FDI) and its interaction with innovation in exporter countries has a positive and significant impact on exports of Asian-10 high-technology products from 2006 to 2013. If there is an increase in the interaction between FDI and innovation of exporter countries, there will also be an increase in exports of Asian-10 hight-technology products.

j. Foreign Direct Investment (FDI) and its interaction with innovation in importer countries has a positive and significant impact on exports of Asian-10 high- technology products from 2006 to 2013. If there is an increase in the interaction between FDI and innovation of importer countries, then the export of high- technology products of Asian-10 countries will decrease.

\section{References}

Botric, V., Sisinacki, J., \& Skuflic, L. (2006). Road Infrastructure and Regional Development: An Evidence From Croatia.

Carbaugh, R. (2010). International Economics: Cengage Learning.

Carrillo, C., \& Li, C. A. (2002). Trade Blocks and the Gravity Model: Evidence from Latin American Countries.

Chen, Y., \& Puttitanun, T. (2005). Intellectual property rights and innovation in developing countries. Journal of Development Economics, 78(2), 474-493. doi: 10.1016/j.jdeveco.2004.11.005

Deliarnov. (2003). Perkembangan Pemikiran Ekonomi. Jakarta: Rajawali Pers.

Eurostat. (2003). Eurostat indicators on High-tech industry and Knowledge - intensive services. Annex 4 - High-tech aggregation by SITC Rev. 3.

Falvey, R., Foster, N., \& Greenaway, D. (2009). Trade, imitative ability and intellectual property rights. Review of world economics, 145(3), 373-404.

Fu, X. (2007). Foreign Direct Investment, Absorptive Capacity and Regional Innovation Capabilities: Evidence from China. 
Greenway, D., \& Yu, Z. (2004). Firm Level Interactions Between Exporting and Productivity: Industry Spesific Evidence. Review of world economics (Welthwirtschafliches Archiv)

Grossman, G. M., \& Helpman, E. (1994). Endogenous Innovation in the Theory of Growth. Journal of Economic Perspectives, 8, 23-44 Gujarati, D. N. (2004). Basic Econometrics: McGraw-Hill.

Hailu, Z. A. (2010). Impact of foreign direct investment on trade of African countries. International Journal of economics and Finance, 2(3), 122.

Ismail, N. W. (2013). Innovation and High-Tech Trade in Asian Countries. Journal of Development Economics.

Keller, W. (2009). International Trade, Foreign Direct Investment, and Technology Spillovers. Journal of Development Economics.

Kimura, F., \& Obashi, A. (2011). Production Networks in East Asia: What We Know So Far.

Krugman, P. R., Obstfeld, M., \& Melitz, M. J. (2012). International Economics: Theory \& Policy: Pearson Addison-Wesley

Lo, S.-t. (2011). Strengthening intellectual property rights: Experience from the 1986 Taiwanese patent reforms. International Journal of Industrial Organization, 29(5), 524-536.

Márquez-Ramos, L., \& Martínez-Zarzoso, I. (2010). The effect of technological innovation on international trade. Economics: the open-access, open-assessment E-Journal, 4, 11.

Onodera, O. (2008). Trade and Innovation Project: A Synthesis Paper. Paris Rogers, E. M. (2003). Diffusion of Innovations, 5th Edition: Free Press.

Rogers, E. M. (2003). Diffusion of Innovations fifth Ed. Free Press. New York.

Salomon, R. M., \& Shaver, J. M. (2005). Learning by Exporting: New Insights from Examining Firm Innovation.

Salvatore, D. (2005). Introduction to International Economics: Wiley.

Schneider, P. H. (2005). International trade, economic growth and intellectual property rights: A panel data study of developed and developing countries. Journal of Development Economics, 78(2), 529-547.

Tambunan, T. (2009). Development of Small and Medium Enterprises in ASEAN Countries: Readworthy Publications.

Verbeek, M. (2004). A guide to Modern Econometrics, $2^{\text {nd }}$ Edition: John Wiley and Sons, Ltd.

Widarjono, A. (2013). Ekonometrika: Pengantar dan Aplikasinya (4 ed.). Yogyakarta: UPP STIM YKPN.

Westphal, L. E. (2002). Technology strategies for economic development in a fast changing global economy. Economics of innovation and new Technology, 11(4-5), 275-320.

Wooldridge, J. M. (2003). Introductory Econometrics: A Modern Approach: South-Western College Pub. 


\section{Appendix}

Appendix 1: Aggregation High-technology products based on the StandardInternational Trade Classification (SITC-Rev.3)

\begin{tabular}{|c|c|}
\hline \multicolumn{2}{|c|}{ Aerospace } \\
\hline 792 & Aircraft and associated equipment \\
\hline 714 & Aeroplane motors \\
\hline 87411 & Other navigational instruments \\
\hline \multicolumn{2}{|c|}{ Computers - Office machines } \\
\hline 75113 & Word-processing machines \\
\hline 7513 & Photo-copying apparatus excluding \\
\hline 752 & Computers \\
\hline 75997 & Parts and accessories of group 752 \\
\hline \multicolumn{2}{|c|}{ Electronics - Telecommunications } \\
\hline 76381 & Video apparatus \\
\hline 76383 & Other sound reproducing equipment \\
\hline 764 & Telecommunications equipment excluding \\
\hline 7722 & Printed circuits \\
\hline 77261 & Electrical boards and consoles $1000 \mathrm{~V}$ \\
\hline 77318 & Optical fibre cables \\
\hline 77625 & Microwave tubes \\
\hline 77627 & Other valves and tubes \\
\hline 7763 & Semi-conductor devices \\
\hline 7764 & Electronic integrated circuits and micro-assemblies \\
\hline 7768 & Piezo-electric crystals \\
\hline 89879 & Numeric recording stays \\
\hline \multicolumn{2}{|c|}{ Pharmacy } \\
\hline 5413 & Antibiotics \\
\hline 5415 & Hormones and their derivatives \\
\hline 5416 & Glycosides, glands, antisera, vaccines \\
\hline 5421 & Medicaments containing antibiotics or derivatives thereof \\
\hline 5422 & Medicaments containing hormones or other products of heading \\
\hline \multicolumn{2}{|c|}{ Scientific instruments } \\
\hline 774 & $\begin{array}{l}\text { Electro-diagnostic apparatuses for medicine or surgery and } \\
\text { radiological apparatuses }\end{array}$ \\
\hline 871 & Optical instruments and apparatuses \\
\hline 87211 & Dental drill engines \\
\hline 874 & Measuring instruments and apparatuses excluding \\
\hline 88111 & Photographic cameras \\
\hline 88411 & Contact lenses \\
\hline 88419 & Optical fibres other than those of heading 7731 \\
\hline
\end{tabular}




\begin{tabular}{|c|c|}
\hline \multicolumn{2}{|c|}{ Scientific instruments } \\
\hline 8996 & Orthopedic appliances \\
\hline \multicolumn{2}{|c|}{ Electrical machinery } \\
\hline 7786 & Electrical capacitors, fixed, variable or adjustable excluding \\
\hline 7787 & Electrical machines having individual functions \\
\hline 77884 & Electric sound or visual signaling apparatus \\
\hline \multicolumn{2}{|c|}{ Non-electrical machinery } \\
\hline 7187 & Nuclear reactors and parts thereof, fuel elements etc. \\
\hline 72847 & Machinery and apparatus for isotopic separation \\
\hline 7311 & $\begin{array}{l}\text { Machine-tools working by laser or other light or photon beam, } \\
\text { ultrasonic electro-discharge or electro-chemical process }\end{array}$ \\
\hline 7313 & Lathes for removing metal \\
\hline 73142 & Otherdrilling machines, numerically controlled \\
\hline 73144 & Other boring-milling machines, numerically controlled \\
\hline 73151 & Milling machines, knee-type, numerically controlled \\
\hline 73153 & Other milling machines, numerically controlled \\
\hline 7316 & Machine-tools for deburring, sharpening, grinding, lapping etc. \\
\hline 73312 & $\begin{array}{l}\text { Bending, folding, straightening or flattening machines, numerically } \\
\text { controlled }\end{array}$ \\
\hline 73314 & Shearing machines, numerically controlled \\
\hline 73316 & Punching machines, numerically controlled \\
\hline 7359 & Parts and accessories of 731- and 733- \\
\hline 73733 & $\begin{array}{l}\text { Machines and apparatuses for resistance welding of metal fully or partly } \\
\text { automatic }\end{array}$ \\
\hline 73735 & $\begin{array}{l}\text { Machines and apparatuses for arc, including plasma arc welding of met- } \\
\text { al; fully or partly automatic }\end{array}$ \\
\hline \multicolumn{2}{|c|}{ Chemistry } \\
\hline 52222 & Selenium, tellurium, phosphorus, arsenic and boron \\
\hline 52223 & Silicon \\
\hline 52229 & Calcium, Strontium and barium \\
\hline 52269 & Other inorganic bases \\
\hline 525 & Radio active materials \\
\hline 531 & Synthetic organic coloring matter and color lakes \\
\hline 57433 & Polyethelene terephthasase \\
\hline 591 & Insecticides, disinfectants \\
\hline \multicolumn{2}{|c|}{ Armament } \\
\hline 891 & Arms and ammunition \\
\hline
\end{tabular}

Source: Euro Statistics (2003) 